\title{
MENCARI BENTUK MENGAJAR ENTREPRENEURSHIP PADA PERGURUAN TINGGI
}

\author{
Bambang Pratama \\ Jurusan Manajemen, Fakultas Ekonomi dan Bisnis, Universitas Bina Nusantara, \\ Jln. K.H. Syahdan No. 9, Palmerah, Jakarta Barat 11480 \\ bambangpratama@binus.edu,bptama@binus.ac.id
}

\begin{abstract}
The high number of unemployment in Indonesia is caused by college graduates not brave enough to determine a career path as an entrepreneur. The embedded bad image and false myths about entrepreneurs has made its spread very low in Indonesia. Universities in Indonesia are looking for a more effective form of teaching entrepreneurship so as to produce graduates who are productive rather than educated, but unemployed graduates. Entrepreneurship is very unique because it contains multiple disciplines. There are various forms of teaching entrepreneurship used by different countries in the world from various literatures. Universities and entrepreneur lecturers should be able to take an example on (adapt and adopt) how to teach according to the college culture and taught students, without having to look at what disciplines the student is enrolled in, also by integrating the values of entrepreneurship in the curriculum and extracurricular activities as supporting activities. Thus, entrepreneurial atmosphere can be created within the campus so that students, during their stay in college, do not seem to have lived and becoming used to a dynamic entrepreneurial environment, inspiring, and full of innovation. Thus, graduates will be braver in becoming an entrepreneur without it becomes their last choice like the current situation.
\end{abstract}

Keywords: higher education, entrepreneurship, students, teaching method

\begin{abstract}
ABSTRAK
Tingginya jumlah pengangguran di Indonesia disebabkan ketidakberanian para lulusan perguruan tinggi untuk menentukan pilihan karir sebagai entrepreneur. Tertanamnya image yang buruk dan mitos-mitos keliru tentang entrepreneur membuat penyebarannya sangat rendah di Indonesia. Perguruan tinggi di Indonesia sedang mencari bentuk pengajaran entrepreneurship yang efektif sehingga menghasilkan lulusan yang produktif, bukan lulusan yang menjadi pengangguran yang terdidik. Entrepreneurship menjadi sangat unik karena di dalamnya multi disiplin ilmu. Terdapat berbagai bentuk pengajaran entrepreneurship yang digunakan oleh berbagai negara di dunia dari berbagai literatur. Seharusnya perguruan tinggi dan dosen entrepreneur dapat mencontoh (adapt and adopt) cara mengajar sesuai dengan kultur perguruan tinggi dan mahasiswa yang diajar, tanpa harus memandang satu disiplin ilmu apa yang harus didalami oleh mahasiswa. Selain itu, juga dengan mengintegrasikan nilai-nilai entrepreneur dalam kurikulum dan ekstrakurikuler sebagai pendukung. Dengan demikian, terciptanya suasana entrepreneurship di dalam kampus sehingga tidak terasa mahasiswa selama studi telah hidup dan terbiasa dalam lingkungan entrepreneur yang dinamis, inspiratif, dan penuh inovasi. Dengan demikian, lulusan akan berani untuk menjadi seorang entrepreneur tanpa harus menjadi pilihan pekerjaan terakhir seperti yang selama ini terjadi.
\end{abstract}

Kata kunci: perguruan tinggi, entrepreneurship, mahasiswa, teaching method 


\section{PENDAHULUAN}

Pola pengajaran entrepreneurship yang tepat di perguruan tinggi selalu menjadi bahan perdebatan yang tidak pernah berakhir seperti mendiskusikan nature vs. nurture. Berangkat dari disiplin ilmu dan keyakinan yang berbeda, maka wajar perdebatan ini tidak pernah berakhir. Tetapi, selain memperdebatkan telur dan ayam, manakah yang lebih dahulu ada? Ada hal yang lebih penting, yaitu output atas metode pengajaran entrepreneurship tersebut. Apakah perguruan tinggi di Indonesia telah mencetak entrepreneur baru yang dilahirkan oleh universitas. Jawabannya adalah belum. Hal ini terlihat dari jumlah entrepreneur di Indonesia yang jumlahnya hanya 400 ribu orang, sedangkan seharusnya adalah 2\% (David McClelland) dari jumlah penduduk Indonesia, yaitu 4,5 juta lebih.

Berkaca pada negara tetangga, Singapura yang jumlah penduduknya hanya 5 juta jiwa lebih, jumlah entrepreneur mencapai 7\% atau 350 ribu, atau dibandingkan dengan Jepang 10\%, Amerika Serikat yang mencapai 12\%, maka di Indonesia jumlahnya masih rendah. Oleh sebab itu, Indonesia juga tidak banyak menyumbangkan 100 orang terkaya di dunia yang $70 \%$ berasal dari pebisnis (Leveraging Time to Create Wealth). Celakanya, jumlah pengangguran di Indonesia yang tinggi, khususnya pengangguran terdidik dan cenderung kian bertambah di tengah terpaan krisis global beberapa tahun belakangan ini. Rendahnya jumlah entrepreneur di Indonesia dikarenakan perilaku tidak berani ambil risiko dan pada umumnya masyarakat lebih memilih jalur aman, yaitu menjadi pegawai negeri (Dwi Larso, IICIES, 2010). Hal ini amatlah bertentangan dengan karakter seorang entrepreneur, yaitu risk taker. Oleh sebab itu, tantangan bagi perguruan tinggi dalam merubah mindset "play safe" menjadi "risk taker" adalah tidakan yang tidak mudah.

Entrepreneurship mempunyai peran yang sangat penting sebagai salah satu pilar ekonomi. Akan tetapi, melihat rendahnya jumlah entrepreneur di Indonesia, maka untuk men-setup mindset baru, dibutuhkan reformasi sistem belajar mengajar pada perguruan tinggi yang inovatif. Menjawab tantangan ini, sesungguhnya bukan menjadi pekerjaan rumah perguruan tinggi sendiri, tetapi memerlukan komitmen yang tinggi dan konsisten dari beberapa unsur, yaitu ABG (Academia, Business, and Government). Beberapa program percepatan entrepreneurship telah digagas oleh pemerintah, di antaranya program hibah berupa modal bagi perguruan tinggi dalam menghasilkan usaha baru pada tingkat mahasiswa. Skim hibah merupakan perangsang bagi mahasiswa yang ingin memulai usaha baru. Umumnya memandang profesi entrepreneur dengan sebelah mata, atau juga pilihan kedua, ketiga dan seterusnya, bukan menjadi pilihan utama apalagi pilihan hidup. Program hibah ini juga menjadi solusi terhadap permasalahan klasik dalam memulai sebuah usaha, yaitu "modal". Dengan program ini, maka dapat menjadi tantangan tersendiri bagi perguruan tinggi dalam menggali kreativitas dan inovasi pada diri mahasiswa dan mengantarkannya sehingga dapat menjalankan usaha melalui pembelajaran entrepreneurship di perguruan tinggi.

Permasalahan dalam penelitian ini adalah (1) Mindset mahasiswa yang keliru tentang entrepreneurship adalah bukan merupakan pekerjaan dan tidak dapat dijadikan profesi dalam mencari uang, (2) Perbedaan mindset antara sesama dosen dalam mengajar entrepreneurship yang lebih banyak menggunakan metode ceramah dan pengkotak-kotakan disiplin ilmu dalam proses pengajaran, mengingat dalam entrepreneurship terdapat beberapa disiplin ilmu, misalnya marketing, management, finance, legal, dan sebagainya, (3) Pengajaran entrepreneurship seharusnya merupakan sebuah sistem pengajaran yang baru, inovatif, dan tidak ortodok. Hal ini tidak boleh hanya disampaikan melalui metode ceramah saja. Mahasiswa harus dapat dirangsang sehingga berani mencoba mempraktikkan sikap seorang entrepreneur dalam proses pembelajarannya, 4) Entrepreneurship seharusnya diajarkan oleh dosen yang juga praktisi bisnis yang masih dijalaninya atau yang pernah dijalani oleh dosen/pengajar. Hal ini diperlukan dalam memberikan gambaran sesungguhnya dalam dunia bisnis karena dalam praktik bisnis kerapkali terjadi perbedaan tajam dengan teori yang selama ini diajarkan. 
Tujuan penelitian ini adalah upaya peningkatan mutu pembelajaran entrepreneurship pada perguruan tinggi dan memberikan saran sebagai salah satu bahan pertimbangan dalam upaya percepatan pertumbuhan entrepreneur muda pada perguruan tinggi. Selain itu, tujuan khusus yang ingin dicapai adalah (1) Upaya merubah mindset mahasiswa dalam memandang entrepreneurship tidak hanya semata-mata sebuah usaha dan sulit untuk berkembang. Entrepreneurship lebih dari itu dan dapat diterapkan tidak hanya pada usaha sendiri saja, tetapi dapat diterapkan dalam sebuah perusahaan, bahkan dapat dilakukan sebagai pemecah masalah sosial (social entrepreneur), (2) Memperkaya wawasan pengajar/dosen entrepreneur dalam menerapkan pada proses belajar mengajar sehingga dapat menggali potensi dan keberanian mahasiswa dalam bertindak seperti seorang entrepreneur, (3) Dengan berbagai macam model pengajaran entrepreneurship, maka pengajar/ dosen dapat mengadopsi dan menyesuaikan metode pengajaran yang paling tepat untuk digunakan dalam proses belajar mengajar entrepreneurship di perguruan tinggi, dan (4) Menjadi salah satu kontribusi dalam memperkaya pengetahuan entrepreneurship dalam dunia pendidikan tinggi.

Istilah entrepreneur berasal dari bahasa Prancis entreprendre, yang artinya mengambil langkah memasuki sebuah aktivitas tertentu atau sebuah enterprise, atau menyambut tantangan. Kata entrepreneur terdapat 3 hal penting, yaitu creativity-innovation, opportunity creation, dan calculated risk-taking. Tiga unsur inilah yang umumnya terdapat di semua entrepreneur manapun. Dalam dunia proses antara inovasi dan opportunity dapat dibolak-balik. Hal ini sifatnya relatif dan tergantung pada situasi, di mana seorang entrepreneur berada dan cara memandang sebuah peluang menjadi market (pasar) atau menemukan sebuah inovasi, lalu menciptakan market.

Tokoh entrepreneur pada masa awal adalah Marco Polo. Pada masa ini, terdapat 2 belah pihak, yaitu pihak pasif dan aktif. Pihak pasif adalah pemilik modal, sedangkan pihak aktif adalah yang menggunakan modal. Pada masa ini, Marco Polo melakukan perluasan perdagangan melalui jalur laut. Ia memiliki ide untuk membuka hubungan dagang dengan Asia pada abad ke-13 dan juga meyakini akan adanya keuntungan lain pada akhirnya. Selanjutnya, perkembangan entrepreneurship pada abad ke-17 tokohnya adalah Richard Cantillon, berpendapat bahwa seorang entrepreneur adalah risk taker. Pada masa ini, entrepreneurship diartikan berhadapan dengan ketidakpastian. Oleh sebab itu, diartikan sebagai pengambil risiko.

Masa selanjutnya adalah pada abad ke-18. Pada masa ini, entrepreneur dilekatkan pada pemilik modal dan dibedakan antara pemodal dengan penemu. Pada masa ke-19, entrepreneurship adalah sebagai pengorganisir dan pengatur sebuah perusahaan dalam memajukan usahanya. Memasuki abad ke-20, entrepreneurship banyak berkecimpung dalam bidang teknologi informasi, lingkungan, dan sosial kemanusiaan. Pemanfaatan teknologi informasi banyak melahirkan usaha-usaha baru yang kreatif dan inovatif. Permasalahan lingkungan pada abad milinenium ini menimbulkan berbagai fenomena sosial lainnya seperti kelangkaan air bersih, minimnya lahan hijau, udara kotor, kemiskinan sampai dengan isu mengenai sampah. Jaman ini menurut beberapa ahli dikatakan sebagai jaman komplesitas dan jaman kekacauan ekonomi, dikarenakan berbagai macam fenomena ekonomi terjadi seperti menguatnya ekonomi China secara spektakuler, diikuti dengan Korea dan Taiwan serta runtuhnya perekonomian Amerika Serikat.

Beberapa macam entrepreneurship menurut Ciputra (2009), yaitu (1) Business entrepreneur. Kelompok ini terbagi menjadi 2 yakni owner entrepreneur dan professional entrepreneur. Owner entrepreneur adalah para pencipta dan pemilik bisnis. Professional entrepreneur adalah orang-orang yang memiliki daya wirausaha, akan tetapi mempraktikkannya pada perusahaan orang lain; (2) Government entrepreneur, adalah pemimpin negara yang mampu mengelola dan menumbuhkan jiwa dan kecakapan wirausaha penduduknya. Contoh dari government entrepreneur adalah pemimpin negara Singapura, Lee Kuan Yew; (3) Social entrepreneur, di mana seseorang yang masuk dalam kelompok ini adalah para pendiri organisasi-organisasi sosial kelas dunia, yang berhasil menghimpun dana masyarakat untuk melaksanakan tugas sosial yang mereka yakini. Contohnya adalah Mohammad Yunus, peraih nobel perdamaian tahun 2006 serta pendiri Grameen Bank; (4) Academic entrepreneur, 
adalah akademisi yang mengajar atau mengelola lembaga pendidikan dengan pola dan gaya entrepreneur, sambil tetap menjaga tujuan mulia pendidikan. Universitas Harvard dan Stanford merupakan beberapa universitas terkemuka yang mengelola dunia pendidikan dengan gaya entrepreneur.

Dari berbagai kelompok entrepreneurship di atas, kesemuanya memiliki kesamaan karakter, yaitu inovasi dan mampu melihat masalah menjadi sebuah peluang serta menciptakan tenaga kerja bagi yang lain. Sampai saat ini entrepreneur masih saja diartikan secara sempit, yaitu umumnya dikatakan sebagai wiraswasta saja, tanpa melihat diri seorang entrepreneur sesungguhnya yang berani, tangguh, kreatif, dan inovatif, yang berjalan di tengah kekacauan dan berbagai masalah sosial.

\section{METODE PENELITIAN}

Metode dalam penelitian ini adalah dengan menggunakan metode deskriptif komparatif, sedangkan topik yang dibahas akan dieksplor dan dijelaskan secara mendalam, yaitu dengan mengkaji secara mendalam dan menggambarkan tentang pengajaran entrepreneurship pada perguruan tinggi dari berbagai negara di dunia. Adapun berbagai bahan kajian ini didapat dari hasil penelitian, seminar internasional dan prosiding, internet, dan buku-buku tentang pengajaran entrepreneurship di perguruan tinggi. Selanjutnya, bahan-bahan pendukung kajian disusun dan disestematisir sesuai dengan kebutuhan penulisan.

\section{HASIL DAN PEMBAHASAN}

\section{Mindset Keliru Tentang Entrepreneur}

Sebelum seseorang berpikir dan menentukan pilihan menjadi seorang entrepreneur, hal yang menjadi ganjalannya adalah mindset salah tentang entrepreneur itu sendiri. Mindset yang salah ditambah dengan mitos-mitos seputar entrepreneur, yang mengatakan bahwa seorang entrepreneur itu harus memiliki modal yang besar, spekulan, bukan pemikir, malas bekerja, tidak memiliki masa depan, dan berbagai mitos buruk lainnya.

Mitos-mitos ini tumbuh sangat kuat di masyarakat dan belum tentu juga apabila ada seorang mahasiswa yang telah menentukan pilihan hidupnya sebagai entrepreneur mendapat ijin dari orang tuanya karena perbedaan mindset itu sendiri. Untuk mengubah paradigma yang salah ini memang sulit dan perlu waktu dan pembuktian yang kuat dalam memecah mitos-mitos tersebut. Padahal, seorang pekerja atau karyawan yang selalu inovatif dan kreatif pada sebuah perusahaan dapat dikatagorikan sebagai intrapreneur.

Entrepreneur dalam arti sempit bukanlah hanya seorang pedagang biasa, tetapi lebih dari itu. Dialah orang pilihan yang memiliki komitmen dan passion yang kuat terhadap bidang yang digelutinya sehingga dalam bekerja selalu melahirkan temuan serta cara baru dan unik. Selain itu, dia juga seorang yang tidak memandang masalah modal sebagai penghalang dalam memulai sebuah usaha, tetapi memandangnya sebagai tantangan. 


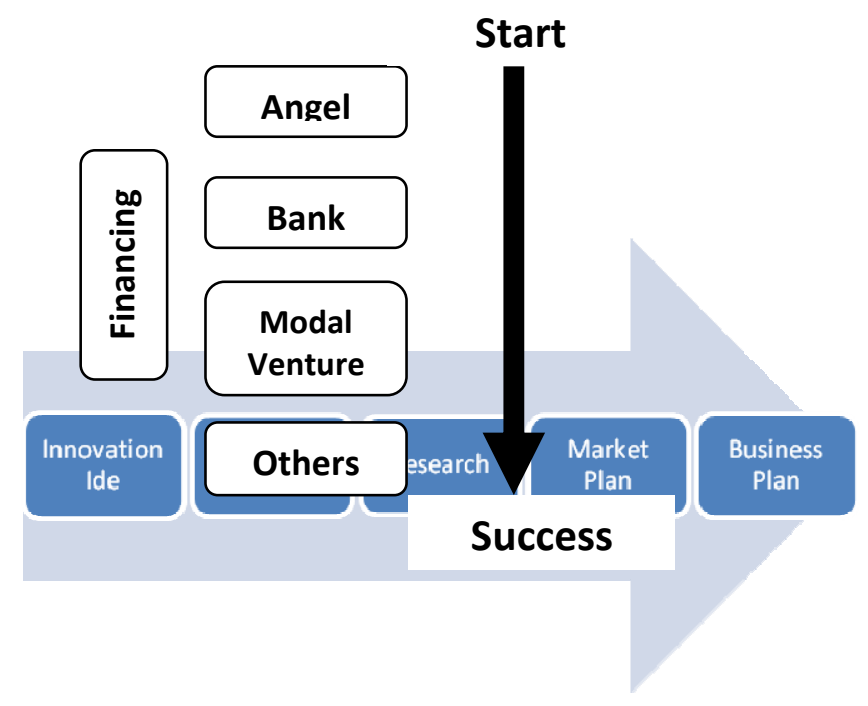

Gambar 1 Proses Menjadi Entrepreneur

Sumber: Yani Panigoro, 2010

Dari skema proses menjadi seorang entrepreneur, dapat terlihat bahwa modal bukan menjadi hambatan. Permodalan merupakan tahapan terakhir dari sebuah proses menuju komersialisasi. Terlihat bahwa dari mulai penggodokan ide dan inovasi sampai dengan bisnis plan merupakan proses yang harus dilalui dengan riset tentang segmentasi pasar. Mindset yang kerapkali keliru dan diyakini oleh banyak orang, termasuk mahasiswa adalah modal merupakan faktor utama yang berada di barisan paling depan dan menjadi ganjalan utama, seharusnya tidak demikian. Dalam membuat sebuah bisnis, masalah yang harus dijawab adalah bagaimana ketajaman dalam melihat sebuah peluang dan memanfaatkannya menjadi sebuah market yang potensial. Sebelum menjalankan sebuah usaha, seorang entrepreneur harus dapat juga melihat prospek ke depan dan menangkap pasar yang akan dituju. Apabila produk yang akan dipasarkan telah melalui proses riset dan pasarnya memang banyak dan menjanjikan, maka modal tidak akan menjadi masalah karena akan banyak investor yang berani memberikan dana.

\section{Kreativitas dan Inovasi dalam Mengajar Entrepreneurship}

Kemampuan seorang entrepreneur dapat diidentikkan dengan penemuan dan inovasi yang berasal dari kreativitas. Inovasi ini lalu dapat dianalisis secara sistematis sehingga hasil akhirnya menjadi kesuksesan (Donald F. Kuratko, 2010), dan dapat melihat sebuah masalah dari sudut pandang yang berbeda sehingga dapat diputarbalikkan menjadi sebuah opportunity atau peluang bisnis. Sesuai apa yang dikatakan oleh Ciputra, seorang entrepreneur adalah orang yang dapat merubah kotoran menjadi emas, misalnya seseorang dapat mengubah sampah menjadi biogas, atau pupuk dan lain sebagainya. Yang terpenting dari solving problem entrepreneur dikatakan sebagai agen-agen perubahan. Hal terpenting yang dilakukannya sesuai dengan permintaan pasar atau yang dibutuhkan oleh masyarakat sehingga menguntungkan. Untuk melakukan ini tidak mudah dan memerlukan proses pembelajaran, wawasan, pergaulan, dan pengetahuan yang banyak. Dari berbagai literatur, terdapat beberapa macam inovasi, yaitu inovasi biasa, inovasi teknologi, dan inovasi luar biasa atau inovasi yang memang belum pernah ada sebelumnya. Jadi, tidak perlu memikirkan yang terlalu jauh apabila memang tidak dapat menemukan sebuah inovasi yang luar biasa karena memang sangat sulit dan memerlukan waktu dan riset yang panjang. Tetapi, akan ada banyak inovasi yang dapat tercipta apabila kita telah mengenali diri kita dengan baik dan melihat sekeliling kita dengan peka dan seksama (Rhenald Kasali, 2010). 
Selain itu, dalam rangkaian sebuah bisnis, yang harus ditentukan adalah bagaimana alur sebuah industinya dari mulai hulu sampai hilir. Tidak semua industri memiliki alur distribusi yang baik, bisa saja seorang entrepreneur menemukan sebuah konsep baru dalam rangkaian proses distribusi yang lancar tanpa memerlukan teknologi tinggi, atau juga tanpa inovasi yang belum pernah ada sebelumnya, tetapi merangkai dan menjaga kestabilan proses tersebut saja. Dengan demikian, ini sudah dapat dikatakan inovasi. Mengapa demikian? Karena sudah menjawab permasalahan distribusi barang tersebut, yang selama ini macet menjadi lancar dan sustain. Kreativitas dan inovasi yang fenomenal umumnya memerlukan imajinasi yang tinggi, tetapi imajinasi yang dapat diaplikasikan pada dunia nyata. Hambatan-hambatan yang timbul biasanya datang dari cara berpikir yang terkotakkotak dan terlalu mengandalkan logika, tidak thinking outside the box. Pemikiran yang terkotak-kotak, kurangnya pengetahuan, hambatan budaya atau kurangnya sarana dan prasarana dalam suatu lingkungan (James L. Adam, 2009).

Hambatan lain adalah lahirnya mitos-mitos bahwa sebuah inovasi harus lahir dalam sebuah proyek yang besar sehingga inovasinya juga besar, atau juga inovasi haruslah terencana dan berbiaya besar. Padahal tidak semua inovasi seperti itu, misalnya temuan Christian Heygens (1629-1695) seorang asal Belanda yang menemukan roda keseimbangan dari sebuah per pegas rakitan dari sebuah jam tangan, padahal jam pertama kali ditemukan oleh Galileo Galilei. Inovasi roda keseimbangan temuan Heygens masih dipakai hingga saat ini pada setiap jam tangan, atau Steve Jobs yang merasa kesal dengan smartphone touch screen yang selama ini menggunakan stylus dan tidak dapat menggunakan jari sehingga akhirnya Apple company mengeluarkan produk pertama kali yang menggunakan teknologi layar sentuh yang pertama yang bernama I-Phone. Di samping itu, Apple tercatat sebagai perusahaan nomer satu di dunia yang paling innovatif.

\section{Model Pengajaran Entrepreneurship}

Model pembelajaran yang efektif adalah bagaimana membuat mahasiswa memiliki pengalaman atas sebuah proyek atau bisnis dalam entrepreneurship (Gambar 2). Yang paling penting juga adalah bagaimana mengeksekusi ide dan pengetahuan sehingga menjadi pengalaman bagi mahasiswa.

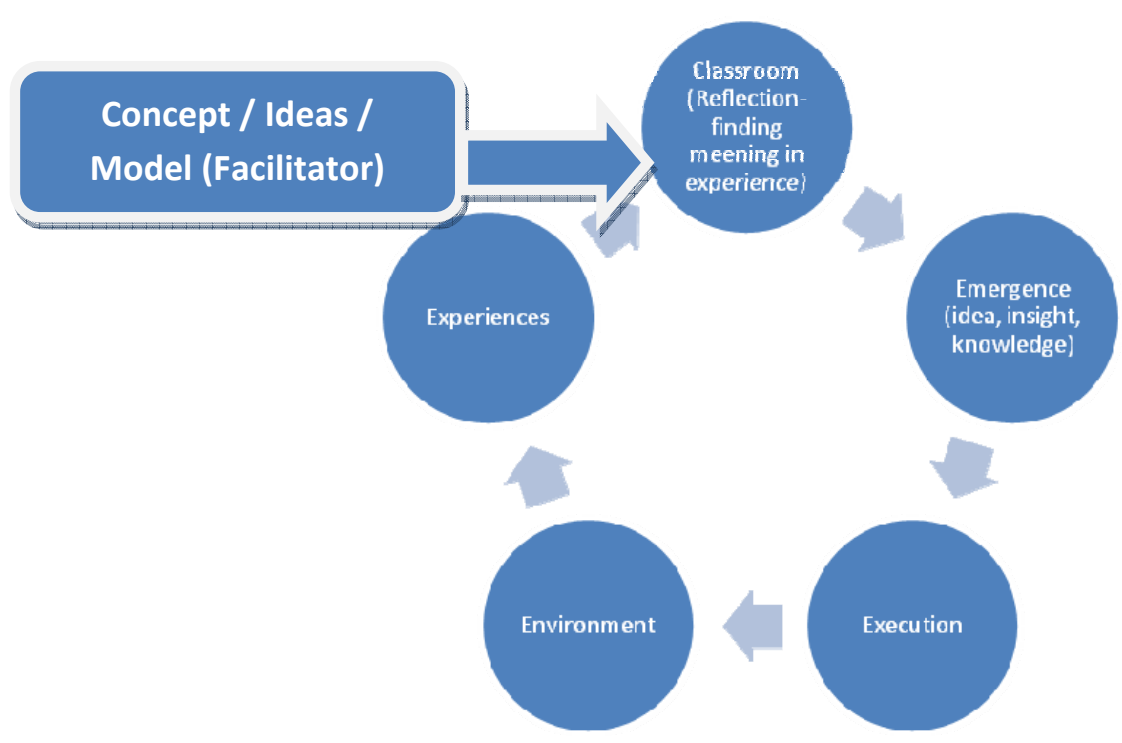

Gambar 2 Learning Effectiveness Model Sumber: The Institute for Enterprise Education 
Banyak perguruan tinggi saat ini membuat entrepreneurship center yang merancang strategi dan konsep pengajaran entrepreneurship. Konsep pengajaran yang sudah dibuat oleh center akan berdampak langsung pada pengajaran di kelas. Pada level kelas menuju pengalaman mahasiswa, memerlukan dukungan pengetahuan, lingkungan, dan implementasi. Tanpa implementasi, proses pembelajaran entrepreneurship tidak akan efektif dan berhenti pada tingkat teoritis saja. Untuk lingkungan, dalam terapan yang dimaksud terdapat berbagai model pengajaran yang berbeda-beda, antara lain sebagai berikut.

Pertama, case studies. Pada metode ini, mahasiswa dapat mempelajari kasus-kasus seputar bisnis, kasus yang dipelajari sifatnya relatif, dan tidak menutup satu kemungkinan saja. Misalnya pada saat Google Corp. meninggalkan China karena tingginya tingkat pembajakan di sana dan jumlah hacker yang tinggi dan mengancam bisnis, maka ditinggalkanlah negara yang pertumbuhan ekonominya sangat fenomenal itu. Case studies yang dipelajari sebaiknya terapan, dan akan lebih baik apabila mempelajari bidang bisnis yang akan digeluti oleh mahasiswa nantinya sehingga dapat mengetahui dunia bisnis tersebut, baik secara nyata maupun faktual.

Kedua, ceramah oleh guest speaker (praktisi). Metode ceramah dengan mendatangkan guest speaker biasanya dilakukan oleh perguruan tinggi pada kuliah perdana atau kuliah umum. Dengan mendatangkan para praktisi yang sesungguhnya dalam dunia bisnis, dapat menggugah rasa keberanian mahasiswa dalam menjalankan bisnis. Biasanya, para praktisi akan menjelaskan tentang pentingnya entrepreneurship sebagai salah satu pilar ekonomi. Juga dengan menceritakan success dan fail story dalam menjalankan bisnis karena pastilah seorang entrepreneur pernah sekali-dua kali mengalami kegagalan. Oleh sebab itu, diperlukan persistensi sehingga terus menjalankan dan akhirnya sukses di kemudian hari. Wawancara secara langsung dengan para praktisi dapat juga dilakukan dalam menggali apa yang sebenarnya menjadi peluang dan inovasi yang dilakukan seorang praktisi untuk bisa sukses dalam menjalankan bisnisnya. Dalam berbagai diskusi dengan praktisi, umumnya mahasiswa menginginkan seorang narasumber yang umurnya relatif muda dan tidak berbeda jauh sehingga bentuk situasi yang dialami oleh praktisi dan mahasiswa tidak jauh berbeda, kemudian dapat dijadikan role model.

Ketiga, membuat proyek dan konsultasi proyek. Pengajaran membuat sebuah proyek juga merupakan salah satu bagian dari pengajaran entrepreneurship pada perguruan tinggi. Metode ini baiknya dilakukan pada jurusan teknik di perguruan tinggi karena pada jurusan teknik mahasiswa dapat dibimbing secara langsung dalam membuat sebuah proyek, sekaligus untuk mempraktikkan bidang ilmu yang didalaminya. Pada kenyataannya, praktik mahasiswa bidang teknik di luar pembelajaran entrepreneurship, mereka umumnya membuat sebuah alat atau sebuah proyek yang tidak mempunyai nilai komersial. Oleh sebab itu, dalam pengajaran entrepreneurship, mahasiswa teknik dimulai untuk membuat sebuah proyek yang memiliki nilai komersial dan mampu diserap oleh industrinya masing-masing. Apabila sejak kuliah para mahasiswa telah banyak membuat karya dan inovasi yang valuable dan pengajar/dosen entrepreneurshipnya dapat mengantarkan pada dunia bisnis, maka pastilah mahasiswa tersebut tidak akan menginginkan bekerja, tetapi malah akan lebih ke arah pengembangan-pengembangan selanjutnya.

Keempat, membuat bisnis plan (venture plan writing). Pembelajaran entrepreneurship yang umum dilakukan pada perguruan tinggi adalah pembuatan bisnis plan sebagai tugas akhir. Secara praktis, bisnis plan yang dibuat seringkali bertolak belakang. Ini didasari karena perbedaan antara kenyataan dengan teori. Secara kerangka teoritis, sebuah usaha yang akan dibuat akan selalu terukur di atas kertas dan kenyataannya adalah beberapa fenomena ekonomi yang terjadi akan berimplikasi tinggi terhadap perhitungan matematis bisnis plan yang dibuat. Dalam pembuatan bisnis plan yang baik, segala aspek dapat dimasukkan dari mulai konsep bisnisnya, inovasi produk ataupun jasa, proyeksi keuangan, modal yang dimasukkan, pemasaran produk atau jasa, analisis pasar yang akan dimasuki, karyawan, perijinan, dan lain sebagainya. 
Selain analisis-analisis di atas, yang tidak dapat dimasukkan adalah sifat dan karakter entrepreneurship itu sendiri, sedangkan roh entrepreneurship seperti persistence, hardworking, dan risk-taking tidak dapat terukur. Sifat dan karakter entrepreneur akan teruji dan terbentuk apabila dilakukan langsung pada dunia nyata. Belum tentu 50\% dari jumlah siswa dalam kelas entrepreneurship akan memiliki mental baja apabila menemui kenyataan ditolak oleh pelanggan, sulitnya menjual dan mencari pelanggan, juga bagaimana menghadapi pelanggan yang judes, dan banyak lagi hal lain yang tidak akan pernah dapat untuk dituliskan dalam bisnis plan.

Kelima, bisnis start up sebagai proses pembelajaran entrepreneurship. Program pengajaran bisnis start up dalam entrepreneurship adalah proses pembelajaran entrepreneurship. Dalam proses bisnis start-up, mahasiswa akan dilatih secara bertahap sehingga dapat benar-benar menjadi seorang entrepreneur oleh pengajar/dosen entrepreneur. Prosesi pengajaran ini dikenal juga dengan istilah coaching. Pelatihan entrepreneurship ini tidak jauh berbeda dengan pelatihan para atlet, hanya berbeda apa yang dilatih dan lapangan tempat latihannya saja.

Para pelatih (coach) entrepreneurship tidak boleh melatih mahasiswa calon entrepreneur yang ingin memasuki industri yang sangat dikuasai oleh coach tersebut. Berbeda dengan pelatihan atlet, dalam entrepreneurship dikatakan berbeda karena apabila coach dan bimbingannya memiliki bidang ilmu bisnis yang sama, dikhawatirkan akan menimbulkan doktrinasi terhadap mahasiswa bimbingannya. Ini berbahaya dan dapat menyebabkan belenggu pemikiran pada mahasiswa bimbingan sehingga mahasiswa calon entrepreneur akan dipaksa melakukan apa yang coach tersebut anggap baik, juga memungkinkan bakal bisnis yang akan dibuat adalah kompetitor coach tersebut sehingga proses pelatihan berjalan secara subjektif dan tidak efektif.

Keenam, simulasi komputer. Media pembelajaran entrepreneurship melalui simulasi komputer dapat digunakan sebagai sarana pembelajaran yang mendekati dunia bisnis sesungguhnya. Simulasi komputer bila diterapkan dalam tingkat kelas, maka akan terdapat berbagai macam (pelaku bisnis) di dalamnya. Ini dimungkinkan untuk mengukur seberapa analisis dan insting bisnis tiap mahasiswa yang memainkan simulasi tersebut.

Sebagai contoh http://www.tombongantuk.com (Purba Daru Kusuma, IICIES, 2010), game ini adalah simulasi game internet untuk melatih pembelajaran entrepreneurship. Dalam game ini, pemain akan dipasangkan sebagai penjual bakmi baru, juga digambarkan siapa saja raja-raja bisnis bakmi terbesar untuk tempat tertentu, seberapa banyak pemain baru di wilayah yang akan dimasuki, stok barang yang akan dijual, dan variasi lainnya. Game ini sangat ringan dan mudah dimainkan, hanya saja tingkat kesulitannya yang terbilang rendah dan masih dalam proses pengembangan untuk level yang lebih sulit dan kompleks. Program simulasi ataupun game simulasi apabila dilakukan secara terus menerus dapat membuat mahasiswa memiliki analisis dan insting bisnis yang kuat karena pada simulasi kerugian, sebuah usaha tidak akan mempunyai dampak apapun, tetapi dalam dunia bisnis sesungguhnya bila rugi, maka dapat menyebabkan rasa putus asa dan takut untuk kembali mencoba bisnis.

Ketujuh, visit study. Metode pembelajaran visit study dilakukan untuk mengetahui seperti apa senyatanya dunia bisnis yang dikunjungi oleh mahasiswa. Dalam visit study ini memiliki kemiripan dengan guest speaker, hanya berbeda dalam visit study mahasiswa dapat melihat langsung segala aktivitas dan prosesnya. Metode ini umumnya dilakukan untuk mengunjungi perusahaan-perusahaan enterprise, jarang dilakukan pada skala usaha kecil atau menengah yang sedang berkembang. Perlunya visit study pada bisnis yang sedang berkembang dapat menjadi pembelajaran mahasiswa melihat proses pertumbuhan bisnisnya karena tidak ada sebuah bisnis yang dapat tumbuh dan berkembang dalam satu malam, kecuali dalam cerita fiksi. Biasanya, dalam visit study mahasiswa diminta untuk membuat sebuah analisis tentang bisnis yang dikunjungi, proyeksi perkembangannya seperti apa, di mana letak inovasi, dan sebagainya. 
Kedelapan, memutar video tentang entrepreneur. Pengajaran melalui pemutaran film atau video pendek tentang kisah seorang entrepreneur dimaksudkan untuk menginspirasikan mahasiswa terhadap dunia bisnis dari pelakunya langsung. Dalam video pendek, biasanya urutan kejadian dan proses perkembangan bisnis dapat digambarkan seperti kenyataan aslinya. Metode ini jarang dilakukan karena minimnya film dokumenter tentang profil pengusaha di Indonesia. Selain penayangan profil pengusaha, memutar video pendek juga dapat secara khusus bagi mahasiswa jurusan desain karena dapat melihat fenomena model desain seperti apa yang sedang menjadi trend di masyarakat.

\section{Pendukung Pengajaran Entrepreneurship di Beberapa Negara}

Perbedaan entrepreneurship antara Eropa dan Amerika Serikat adalah pada definisi dan fokus entrepreneurship nya. Di Amerika, umumnya mengacu pada pertumbuhan usaha atau perusahaan, sedangkan di Eropa dipersamakan dengan usaha kecil dan menengah. Dikarenakan di Eropa banyaknya usaha kecil dan menengah yang melegenda dan jumlah family business yang masih bertahan hingga kini. Perusahaan-perusahaan ini yang hingga saat ini memiliki pengaruh yang kuat bagi ekonomi Eropa yang dijuluki dengan invisible giant.

Selain pengajaran kelas entrepreneurship, juga memerlukan support pengajaran yang lainnya (ekstrakurikuler) seperti seminar, workshop, dan lain sebagainya. Berdasarkan survei 31 negara dan 21 anggota Uni Eropa tahun 2008, pengajaran entreprenuership yang dilakukan adalah seperti pada Tabel 1.

Tabel 1 Ektrakurikuler Pengajaran Entrepreneurship

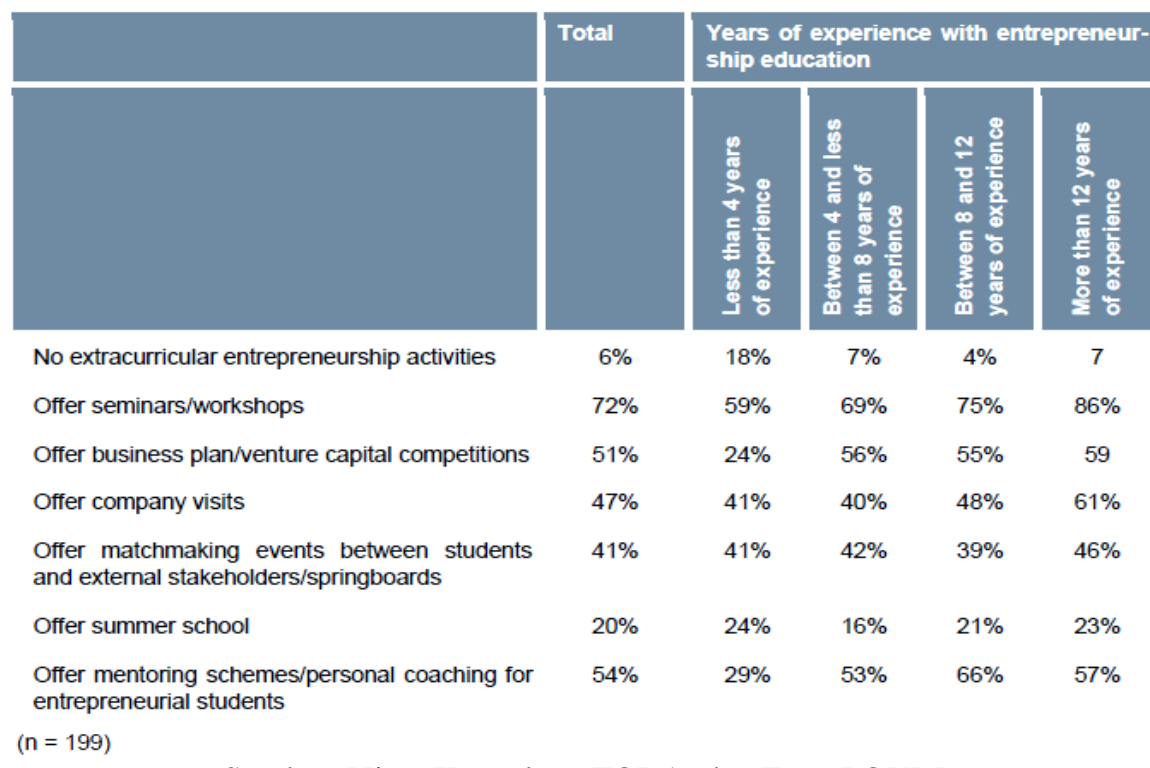

Sumber: Niras Konsultan, FORA, dan Econ POYRI

Dari Tabel 1, terlihat bahwa ektrakurikuler pengajaran entrepreneurship dilakukan terbanyak melalui cara seminar dan workship, lalu diikuti dengan visit study pada industri yang diinginkan, sedangkan kompetisi bisnis plan juga dijadikan sebagai bagian dari ektrakurikulernya. Sementara itu, untuk metode mengajar, yang paling banyak digunakan berdasarkan survei tersebut adalah seperti pada Tabel 2. 
Tabel 2 Metode Mengajar Entrepreneurship

\begin{tabular}{l|c|c|c|c|c} 
& $\begin{array}{l}\text { Average } \\
\text { (interval 1-4) }\end{array}$ & Often & Sometimes & Rarely & Never \\
\cline { 1 - 2 } & 1.38 & $75 \%$ & $17 \%$ & $8 \%$ & $0 \%$ \\
Lecturing & 1.45 & $61 \%$ & $36 \%$ & $3 \%$ & $1 \%$ \\
Case studies & 1.62 & $45 \%$ & $49 \%$ & $4 \%$ & $2 \%$ \\
Entrepreneurs/practitioners in the classroom & 1.54 & $58 \%$ & $35 \%$ & $5 \%$ & $1 \%$ \\
Project teams & 2.16 & $17 \%$ & $51 \%$ & $28 \%$ & $3 \%$ \\
Vempany visits & 2.13 & $31 \%$ & $39 \%$ & $19 \%$ & $11 \%$ \\
Others & 2.68 & $27 \%$ & $16 \%$ & $14 \%$ & $43 \%$
\end{tabular}

Sumber: Niras Konsultan, FORA, dan Econ POYRI

Bedasarkan Tabel 2, dapat terlihat bahwa pembelajaran entrepreneurship dengan metode ceramah masih terbanyak digunakan, lalu diikuti dengan case studies, proyek, dan visit study. Metode pengajaran entrepreneurship harus diubah menjadi metode pembelajaran action-oriented, yaitu berinteraksi langsung dengan praktisi bisnis (baik yang sukses maupun yang tidak sukses), pembuat kebijakan (pemerintah), dan investor (Prof. Arunaditya Sahay, OECD International Confrence Fostering Entrepreneurship: The Role of Higher, Trento, Italy, 2008).

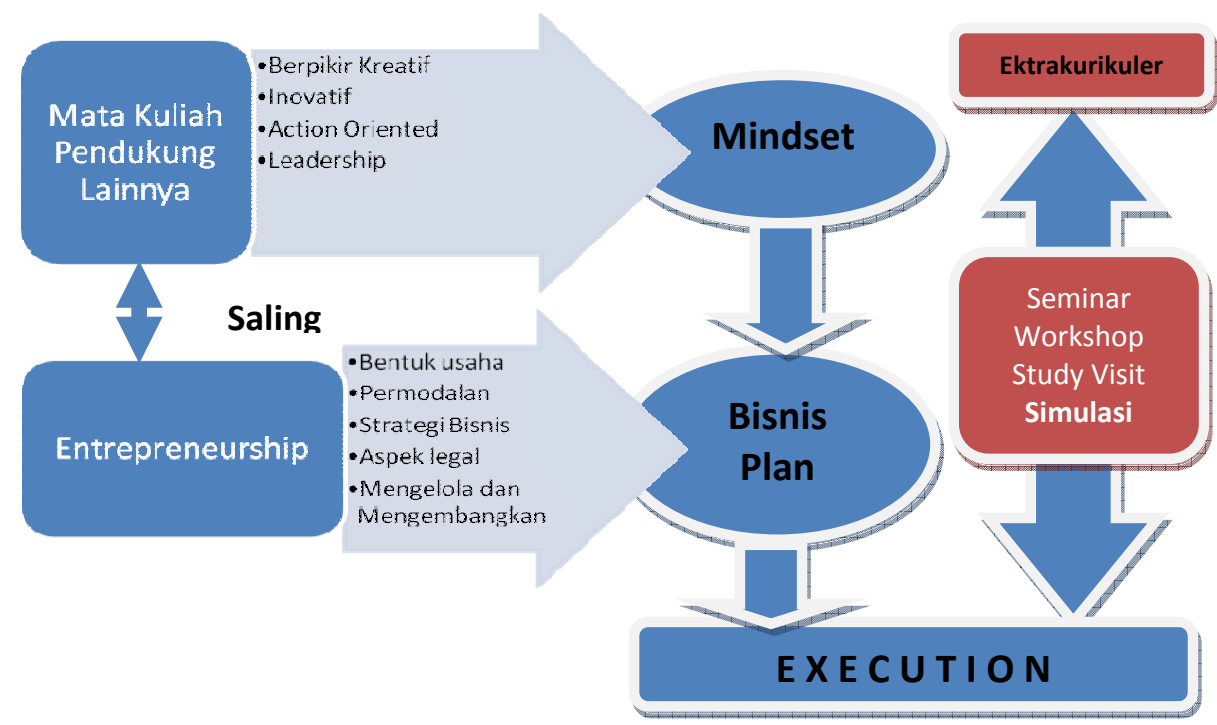

Gambar 3 Skema Pembelajaran Entrepreneurship pada Perguruan Tinggi Sumber: Diolah penulis (Juli, 2010)

Dengan konsep pembelajaran-pembelajaran yang saling mendukung dengan mata kuliah lain (terintegasi), ditambah dengan ektrakurikuler, seharusnya jumlah entrepreneur yang dihasilkan dari perguruan tinggi akan terjadi percepatan. Program yang sudah linier dan saling mendukung dapat menjadi sebuah lingkungan entrepreneur dalam dunia perguruan tinggi. Mata kuliah entrepreneurship akan didukung oleh mata kuliah lain yang memungkinkan untuk diintegrasikan nilai-nilai entrepreneurship sehingga pada saat mahasiswa mempelajari entrepreneurship tidak kesulitan dalam merubah mindset mahasiswa, dapat langsung pada pendalaman bisnis yang akan digeluti nantinya. Sedangkan pasca pembelajaran entrepreneurship, mahasiswa dapat mulai mencari proyek atau inovasi 
dari mata kuliah lain berbekal pengalaman entrepreneurship yang didapat sehingga nantinya inovasi dan kreativitas yang ditemukan dapat sesuai dengan kebutuhan pasar dan industrinya masing-masing.

Untuk pembelajaran pada perguruan tinggi yang sudah inline, maka dari mulai perekrutan mahasiswa baru seharusnya sudah dimulai cluster mahasiswa yang tertarik untuk mendalami entrepreneur, dari mulai perbedaan gender, minat, dan pilihan entrepreneurship yang diinginkan, misalnya pendalaman pada family business, creative industry dan pembidangannya masing-masing serta sosial entrepreneurship. Dengan pembidangan sejak perekrutan mahasiswa baru, hasil akhir yang dapat dicapai adalah penguasaan yang mendalam tentang entrepreneurship dan pembelajarannya akan semakin efektif karena didasari oleh minat dan bakat yang akan dikembangkan oleh mahasiswa itu sendiri. Dengan demikian, entrepreneurship dapat berubah menjadi pilihan utama pada saat mahasiswa lulus kuliah tanpa harus bekerja terlebih dahulu; dengan alasan untuk mencari pengalaman karena selama kuliah pengalaman tentang dunia bisnis telah dialami terlebih dahulu.

\section{Menanamkan Karakter Entrepreneurship pada Mahasiswa}

Penanaman nilai-nilai entrepreneurship dapat menumbuhkan kompetensi yang baru dan unik pada diri mahasiswa. Menurut Suryana, kompetensi adalah seseorang yang memiliki ilmu pengetahuan, keterampilan dan kualitas individu, yang meliputi sikap, motivasi, nilai serta tingkah laku yang diperlukan untuk melaksankan pekerjaan atau kegiatan. Menurut Macffoedz, memberikan pemahaman wirausaha tidak hanya memerlukan pengetahuan, tetapi juga keterampilan. Keterampilanketerampilan tersebut di antaranya adalah keterampilan manajerial (managerial skill), keterampilan konseptual (conceptual skill), dan keterampilan merumuskan masalah dan mengambil keputusan (decision making skill), keterampilan memahami, mengerti, berkumunikasi dan berelasi (human skill) serta keterampilan mengatur dan menggunakan waktu (time management skill) dan keterampilan teknik lainnya. Entrepreneurship juga dapat diterjemahkan sebagai pembelajaran kehidupan dunia nyata yang sesungguhnya dan proses, dari mulai ide sampai dengan implementasi, pembelajarannya, baik selama dalam pendidikan di perguruan tinggi maupun setelah itu. Komponen nilai-nilai yang tertanam dapat menimbulkan manusia yang tangguh dan siap berkompetisi man to man competition. Proses pengajaran berbasis action-oriented diharapkan dapat mengajarkan agar tertanam nilai-nilai entrepreneurship pada diri mahasiswa, sesuai dengan karakter seorang entrepreneur.

Entrepreneursip akan selalu menjadi sebuah teori belaka apabila selalu dipelajari secara keilmuan murni. Karena sifatnya yang unik, entrepreneurship adalah penggabungan dari sebuah skill dan harus didukung oleh science. Tidak semata-mata keilmuan belaka yang hanya mengajarkan bagaimana caranya berhitung keuangan, atau memasarkan produk dengan memperhitungkan kompetitor yang ada. Tetapi lebih dari itu, penanaman fighting spirit yang kuat pada diri mahasiswa sehingga dapat menyadari tantangan ke depan yang semakin kompleks dan kompetitif.

\section{Menggali Ide pada Mahasiswa}

Pembelajaran entrepreneurship dalam prosesnya dapat menggali ide kreatif pada mahasiswa yang memiliki nilai komersial dan dilanjutkan menjadi inovasi atau temuan sesuatu yang baru. Catatan penting dalam sebuah inovasi adalah menentukan arah inovasi tersebut. Inovasi bermacam-macam, tetapi inovasi yang memiliki nilai jual bagi dunia industri yang dihasilkan oleh perguruan tinggi di Indonesia jumlahnya sangat sedikit. Ini merupakan tantangan baru yang harus dijawab oleh perguruan tinggi melalui entrepreneurship.

Sebuah riset yang akan dilakukan memerlukan biaya yang tepat, dan output dari riset tersebut haruslah berguna bagi industri. Upaya mensinergikan hal ini memerlukan linkage dari ABG (Academia, Business, and Government) dan mememerlukan komitmen yang tinggi dan menentukan arah. Apakah bisnis menentukan arah inovasi atau perguruan tinggi atas hasil riset dan kembangan 
berbagai ilmu dapat memproyeksikan arah bisnis dan inovasi yang diperlukan di kemudian hari. ABG sebagai 3 serangkai komponen tidak dapat dipisahkan dan harus berjalan seirama, saling mendukung, dan saling menguntungkan.

Pada suatu situasi tertentu, inovasi yang lahir dari perguruan tinggi sangat memiliki nilai komersial, tetapi praktik komersialisasi produk sehingga mampu diterima oleh pasar perguruan tinggi tidak dapat berjalan sendiri sehingga memerlukan bantuan bisnis, dan pada tatanan tertentu memerlukan bantuan kebijakan pemerintah juga karena apabila tidak bergandengan dengan pemerintah, maka peraturan yang tidak mendukung situasi bisnis tersebut dapat menimbulkan barrier dalam penyebarannya.

\section{Memilih Model Pengajaran Entrepreneurship dan Linkage}

Selain tatanan hubungan di luar perguruan tinggi, maka yang perlu dilakukan adalah adaptasi metode pengajaran sehingga tepat sasaran. Dari berbagai model pengajaran, entrepreneurship haruslah menjadi pendukung dalam mencetak entrepreneur yang lahir dari perguruan tinggi. Adaptasi model pengajaran ini sifatnya relatif dan tidak dapat dipersamakan antara perguruan tinggi satu dengan yang lainnya karena kultur dan karakteristik masing-masing sangat beragam (Abdul Aziz Bin Abdul Latif, Ghazali Ahmad, IICIES, 2010). Oleh sebab itu, pada praktiknya tidak ada satu metode yang paling baik, satu sama lain saling melengkapi tergantung tools seperti apa yang akan dipilih oleh perguruan tinggi masing-masing.

Filosofi pengajaran 3 dinding Ki Hajar Dewantara memiliki makna mendalam bagi pengajaran entrepreneurship. Tiga dinding berarti kelas tanpa satu sekat, yaitu dengan membuka sekat terhadap dunia luar (bisnis). Mahasiswa harus dapat diajak melihat dunia bisnis dengan senyatanya tanpa ada batasan dapat menimbulkan rangsangan dan keberanian tersendiri bagi tiap-tiap mahasiswa untuk membuat sebuah inovasi yang valuable, maka bentuk pengajaran entrepreneurship ini juga harus menyangkut daya cipta (kognitif), daya rasa (afektif), dan daya karsa (konatif)) "educate the head, the heart, and the hand".

\section{SIMPULAN}

Merubah mindset tentang entrepreneurship merupakan tantangan yang terberat dalam mengajarkan entrepreneurship. Oleh sebab itu, memerlukan dukungan pembelajaran yang lain seperti ektrakurikuler dan integrasi pada nilai-nilai entrepreneurship pada kurikulum peguruan tinggi. Sealain itu, diperlukannya kesamaan mindset pada pengajar/dosen entrepreneurship bahwa dalam proses pengajaran, yang perlu dilakukan adalah action-oriented sehingga para pengajar sepakat bahwa hasil akhirnya yang menjadi penentu dalam pengajaran entrepreneurship. Dengan demikian, tidak terjadi sekat-sekat keilmuan dan pembatas antara kelas dengan dunia luar/industri dalam proses belajar mengajar. Dari berbagai macam metode dan model pengajaran entrepreneurship yang dilakukan di berbagai negara, tiap-tiap perguruan tinggi dapat memilih dan mengadaptasikan (adapt and adopt) cara yang tepat dan telah disesuaikan dengan karakteristik mahasiswa dan perguruan tinggi masingmasing. Untuk peningkatan dan efektivitas pengajaran entrepreneurship pada perguruan tinggi, nilainilai entrepreneurship itu sendiri harus sudah dapat diintegrasikan ke dalam kurikulum sehingga secara tidak langsung, mahasiswa selama masa studinya telah hidup dalam lingkungan entrepreneurship. Selain itu, perguruan tinggi dapat melakukan clustering sejak perekrutan mahasiswa baru sesuai dengan minat dan bakat entrepreneurship yang akan didalami mahasiswa nantinya, dari mulai jenis-jenis entrepreneurship yang akan dimasuki, jenis industrinya dan menyesuaikan dengan jurusan yang akan diambil oleh mahasiswa itu sendiri. Dengan demikian, pada saat lulus mahasiswa telah berbekal pengetahuan keilmuan, dengan tertanam jiwa entrepreneurship yang tinggi. 


\section{DAFTAR PUSTAKA}

Abdul, A., and Ghazali, A. (2010). Opportunities for cross boarder entrepreneurship education in ASEAN region, IICIES International Seminar, SMB-ITB dan UMN, Banten.

Abhishek, N., and Arunaditya, S. (2008). Entrepreneurship: A paradigm shift in pedagogy, OECD International Conference on Fostering Entrepreneurship: The role of higher education, Trento, Italy.

Anonim. (2010). Beranikah anda membakar kapal anda. Diakses dari http://einvesti.blogspot.com/2010/01/entrepreneurship-beranikah-anda.html.

Anonim. (2010). Entrereneurship dilahirkan atau diajarkan. Diakses dari http://www.ciputra.org/node/74/entrepreneur-dilahirkan-atau-diajarkan.htm?page=0\%2C1.

Anonim. (2010). Indonesia minim entrepreneur. Diakses dari http://www.stiemdp.ac.id/?pilih=news\&mod=yes\&aksi=lihat\&id=16.

Anonim. (2010). Inovasi tidak sengaja dari seorang dutch. Diakses dari http://kompetiblog2010.studidibelanda.com/inovasi-tak-sengaja-dari-seorang-dutch/.

Anonim. (2010). Jumlah entrepreneur kurang karena orang Indonesia takut ambil risiko. Diakses dari http://roniyuzirman.wordpress.com/2010/07/14/jumlah-entrepreneur-kurang-karena-orangindonesia-takut-ambil-risiko/.

Anonim. (2010). Pemikiran ki hajar dewantara tentang pendidikan. Diakses dari http://www.bruderfic.or.id/h-59/pemikiran-ki-hajar-dewantara-tentang-pendidikan.html.

Anonim. (2010). Pendidikan entrepreneurship di UGM. Diakses dari http://pasca.ugm.ac.id/id/news.php?news id=1.

Anonim. (2010). Sejarah dan pengertian kewirausahaan. Diakses dari http://avin.filsafat.ugm.ac.id/index.php?option=com_content\&task=view\&id=20\&Itemid=34.

Anonim. (2010). Yang terlupakan dari ki hajar dewantara. Diakses dari http://www.wikimu.com/News/DisplayNews.aspx?id=2248.

Anonym. (2010). Teaching entrepreneurship in colleges and universities: How (and why) a new academic field is being built. Retrieved from http://www.kauffman.org/entrepreneurship/teaching-entrepreneurship-in-colleges.aspx.

Anonym. (2010). The 50 most innovative company. Retrieved from http://www.businessweek.com/interactive reports/innovative 50 2009.html.

Anonym. (2010). The history of entrepreneurship. Retrieved from http://www.brighthub.com/office/entrepreneurs/articles/40782.aspx.

Daru Purba, K. (2010). Juragan bakmi scenario design as a culinary business game, IICIES International Seminar, SMB-ITB dan UMN, Banten. 
Eugene, L. (2008). Entrepreneurship education in an age of chaos, complexotu and disruptive change, Institute for Enterprise Education and Brock University Canada, Entrepreneurship in Higher Education, OECD.

European Commision Directorate-General of Enterprise and Industry. (2008). A survey of entrepreneurship in igher education in europe, NIRAS Consultant, FORA, Econ POYRY.

George, S. (2008). Entrepreneurship education in the United State, George Washington University, United States, Entrepreneurship in Higher Education, OECD.

Karen, W. (2008). Entrepreneurship education in Europe, European foundation for entrepreneurship research, entrepreneurship in higher education, OECD.

Kuratko, F.D., and Richard, H.M. (2010). Entrepreneurship theory, process, and practice, $8^{\text {th }}$ ed., Thomson South-Western.

Sutoyo. (2010). Urgensi menumbuhkembangkan entrepreneurship di perguruan tinggi. Diakses dari http://www.upnyk.ac.id/main/?mod=berita\&nid=1564.

Yani, P. (2010). Entrepreneurship masa kini, IICIES International Seminar, SMB-ITB dan UMN, Banten. 